\title{
The influence of lithology and depth on acoustic velocities in South-east Niger Delta, Nigeria
}

\author{
I.Tamunobereton-ari, V. B. Omubo-Pepple, Uko, E.D \\ Department of Physics, Rivers State University of Science and Technology, \\ Port Harcourt 500001, Nigeria. \\ Corresponding author's E-mail: omubopepple@yahoo.com
}

\begin{abstract}
In this paper, composite well log (gamma ray, sonic and density) was used to identify thin layers of different lithologies and the lithologic boundaries at various depths by the signature records of the logs, and checkshot data were used to check and/or validate the integrated time and sonic derived velocities. The results show that acoustic velocities are very much affected by different lithologic properties and depth; porosity decreases more in shale than sandstone and velocity increases more in shale than sandstone all with respect to depth. The result further showed that there was normal parametric trend for both wells from $120 \mathrm{~m}$ to about $3450 \mathrm{~m}$ depth beyond which overpressure sets in.
\end{abstract}

Keywords: Lithology, acoustic velocity, porosity, overpressure, depth of burial, logs, density

\section{INTRODUCTION}

Acoustic velocity is a geophysical parameter that measures the rate of change of displacement as sound wave is propagated through the stratified geology of an area from the source to receiver (Sheriff, 1991). The variation of acoustic velocity with depth is associated with lithologic properties: particles size, density, porosity, confining pressure, pore fluid content, particle orientation etc. strong velocity variations both vertically and laterally are associated with complex overburden structures; examples are the imbricate structure in folded belts involving both Paleozoic and younger rocks, salt diaprism, voids and dipping strata (Judson et al., 1980; Plona and Johnson, 1984).

Some researchers distinguish lithologies based on geologic age, but in this study lithology is considered from its composition and particle size. Different lithologies have different mineralogical compositions and particle sizes based on the source materials, and depositional environments, which influence the temperature and velocity of such formations (Plummer and McGeary, 1993; Uko et al., 2002). Vertical profiling can be used to identify lithologic boundaries, faults, bedrock topography; including structural highs and buried channels, it can also be used to predict overpressure zones and reservoirs. Velocity variations are known to correlate well with the lithological character of the formation materials, thus, providing important structural and lithological information as well as information on dynamic soils and rocks properties for earthquake designed analysis of structures (Bosch et al., 2002; Polymenakos et al., 2005).

It has also been long recognized that the destructiveness of ground shaking during earthquakes can be significantly enhanced by local soil conditions, a term that refers to the mechanical properties of the surficial geological formations. Thus, during past earthquake events, the observed variability in seismic intensity, attenuation and structural damage has been often attributed to the variability of the lithologic stratigraphy and the depth of the earthquake focus of a given area (Assimaki, et al., 2006). Observations of ground motion recorded in the past reveal in many cases that lithologic characteristics had significance influence on the amplitude level, frequency composition, and duration of surface ground shaking of a seismic wave. Therefore, the detailed description of local geological conditions at any site is critical for the assessment of seismic risk for microzonation studies and for the seismic design and retrofit of important facilities and long structures.

It was also observed that the character of the seismic response; microearthquakes or seismic tremor to slow slip on subduction thrusts and other large faults is largely dependent on the lithological conditions of the formations (Shelly et al., 2007; Payero et al., 2008; Delahaye et al., 2009).

The area of this study; the South-east of Niger Delta basin is distinctly made up of three major layers of formations: the Benin, the Agbada, and the Akata 
formations with estimated thickness of each formation ranging from $3000 \mathrm{~m}$ to $5000 \mathrm{~m}$. Figure 1 shows the area of study (Short and Stauble, 1967). Within these major formations lie several minor strata of various dimension and unique characteristics as shown by Figure 2. For water, oil and mineral exploration, drilling and mining, engineering design of structures and environmental studies; it is very important and necessary to understand the compositions of these minor strata and their distribution within the major formations (Prasad, 2002). The propagation characteristics of acoustic waves and their velocities; depend on the elastic constants and densities of the formation materials, that are dependent on their lithologies and depth of burial, which is established by Hooke's relations, given as:

$$
E=\frac{d^{2} u}{d x^{2}} d x d A=\rho \frac{d^{2} u}{d t^{2}} d x d A
$$

Equation (1) can be re-written as

$$
\frac{d^{2} u}{d x^{2}}=\frac{\rho}{E} \frac{d^{2} u}{d t^{2}}
$$

Where $E$ is the elastic constant and $\rho$ is the density of materials, and classical one-dimensional wave equation is given as:

$$
\frac{d^{2} q}{d x^{2}}=\frac{1}{v^{2}} \frac{d^{2} q}{d t^{2}}
$$

Comparing Eqns (2) and (3), velocity, $v$ becomes:

$$
v=\sqrt{\frac{E}{\rho}}
$$

The three-dimensional wave equation, which can be derived in a similar way is essentially analogous; for compressional deformation, is given as:

$$
\frac{\partial^{2} \theta}{d x^{2}}+\frac{\partial^{2} \theta}{d y^{2}}+\frac{\partial^{2} \theta}{d z^{2}}=\frac{\rho}{\lambda+2 \mu} \frac{\partial^{2} \theta}{d t^{2}}
$$

Where $\theta$ is the cubical dilatation

For shear deformation, it is given as:

$$
\frac{\partial^{2} \alpha}{d x^{2}}+\frac{\partial^{2} \alpha}{d y^{2}}+\frac{\partial^{2} \alpha}{d z^{2}}=\frac{\rho}{\mu} \frac{\partial^{2} \alpha}{d t^{2}}
$$

Where $\alpha$ is the shear strain.

By comparing Eq (3) with Eqs (5) and (6), it simply shows that the velocity $v_{p}$ for compressional wave is: $v_{p}=\sqrt{\frac{\lambda+2 \mu}{\rho}} \equiv \sqrt{K+\frac{4 \mu}{3}} \quad$ (7) Where $\lambda=$ $K-\frac{2 \mu}{3}$ and $K$ is the bulk modulus.

The velocity $v_{s}$ for shear wave is

$$
v_{s}=\sqrt{\frac{\mu}{\rho}}
$$

Where $\lambda$ and $\mu$ are the elastic constants. These equations show that the amplitude, frequency and attenuation of acoustic velocities are mainly dependent on the lithology, density and the depth at which the wave is propagated (Udias, 1999).

\section{METHOD}

To precisely determine the influence of lithology and the depth of burial of a geologic formation on acoustic velocities, geophysical well logs and check shot data were used. This is because borehole measurements provide direct in-situ evidence of nonlinearity. Well logs provide a better representation of in-situ conditions in a lithologic unit by providing information on the nature of the strata penetrated, the size and shape of the structures, the depth at which these rocks are encountered, the porosity and permeability of the rock units, type of fluids contained therein and the depth of the fluid interfaces etc., of the subsurface formations penetrated in the area (Brigand et al., 1990).

Two composite well logs comprised of gamma ray log, bulk density log and sonic log were used in this work, which are carefully selected from two well of the same location in the area of study. The signatures of the logs obtained from the runs were carefully digitized to obtain the recorded data. The gamma ray log was used to delineate the different lithologies, and established the sand to shale ratio. The bulk density log was used to determine the densities of the formation materials at various depths. While the sonic log was used to determine the transit time, which was then used to compute for the velocities and porosities at various depths as a function of lithology. Sand to shale ratios, densities, and transit times were all read and determined from gamma ray log, bulk density log and sonic log respectively. From the sonic logs, equation (9) was used to compute the porosities of the formations at various depths (Schlumberger, 1987; Fraser, 1935). 


$$
\Phi=\frac{t_{\log }-t_{m a}}{t_{f}-t_{m a}} \times \frac{100}{1}
$$

Where $\Phi$ the porosity, $t_{\log }$ is the transit time read from the log, $t_{m a}$ is the transit time of the matrix, and $t_{f}$ is the transit time of the fluid present in the formation. The transit velocity was computed as the reciprocal of the transit time read from the log; given as:

$$
V=\frac{1}{t_{\log }}
$$

The gamma ray log was measured in American Petroleum Institute (API) values ranging from 0 to 150 from left to right, the lower the value; sandy the formation materials become, and higher the value; shaly the formation materials become. In delineating the lithologies (sandstone and shale) the depths for sandstone bed and shale bed was chosen based on the peaks of the signatures in the sand zone and in the shale zone respectively to clearly distinguish between sandstone bed and shale bed. The sonic log is measured in microsecond per feet $(\mu \mathrm{s} / \mathrm{ft})$ ranging from 40 to 140, from right to left. The bulk density log is measured in gram per cubic centimeter $\left(\mathrm{g} / \mathrm{cm}^{3}\right)$ ranging from 1.95 to 2.95 , from left to right. The logged depth for well $E$ is from $1405 \mathrm{~m}$ to $4040 \mathrm{~m}$, while the logged depth for well $F$ is from $1390 \mathrm{~m}$ to $3400 \mathrm{~m}$. Checkshot is a vertical seismic profiling method of wells to determining the average velocity as a function of depth by lowering a geophone or geophones into a borehole and recording energies or signals from sources on the surface; often run in addition to sonic log to check and/or validate the integrated time. An illustration of checkshot survey is shown by Figure 3 . In well $E$, the checkshots were taken from depth $120 \mathrm{~m}$ to $2090 \mathrm{~m}$, and for well $\mathrm{F}$; checkshots were taken from depth $476 \mathrm{~m}$ to $2046 \mathrm{~m}$

Figure 4 above is a typical example of composite log; including gamma ray log, sonic log and density log etc., run through a well, showing the signatures and the colour codes of different formation materials and fluid contents. The checkshots data were used to cross-check and validate the trend of the sonic log derived velocities of the formations.

\section{RESULTS AND DISCUSSIONS}

The numerical data obtained from the digitized logs from the two wells (Well $E$ and Well $F$ ) are given in Tables 1 and 2 showing the selected depths, sand and shale percentages, transit times, porosities, acoustic velocities and densities. Considering the observed relationship between the parameters for both sandstone beds and shale beds of Well E, Figure 5 shows that porosity decreases with depth from $1408 \mathrm{~m}$ down to $3650 \mathrm{~m}$ beyond which the normal trend deviated; as porosity started increasing with depth indicating an overpressure. The trend of density - depth relationship for well $\mathrm{E}$ was normal; density increases with depth as shown by Figure 6 . Also, for well $\mathrm{E}$, as shown by Figure 7, velocity increases with depth from $1408 \mathrm{~m}$ down to $3650 \mathrm{~m}$ beyond which the trend deviated; velocity increases with depth indicating an overpressure. For well $F$, as shown by Figure 8; porosity decreases with depth from $1395 \mathrm{~m}$ to $3200 \mathrm{~m}$; beyond which a slight point of deviation was observed. Density increases with depth, shown by Figure 9 is normal trend. Also, for well $\mathrm{F}$ as shown by Figure 10; velocity increases with depth from $1395 \mathrm{~m}$ to 3200 ; beyond which a slight deviation was observed. Comparing both lithologies (Shale bed and sandstone bed) to the trend relationship, it was observed that approximately at same depth, shale is denser than sandstone, because shale undergoes plastic compaction or deformation while sandstone undergoes elastic compaction or deformation (Plummer and McGeary, 1993). Porosity decreases more with depth in shale bed than sandstone bed at approximately same depth. Also, from Figures 7 and 10, velocity increases more in shale than sandstone in both wells $\mathrm{E}$ and $\mathrm{F}$. With respect to checkshot data, Figure 11 and 12 for wells $E$ and $F$ respectively clearly show that velocity increases with increasing depth across the different lithologies. 
Am. J. Sci. Ind. Res., 2010, 1(2): 279-292

Table 1a: Petrophysical Parameters for Well E. Shale Bed

\begin{tabular}{|c|c|c|c|c|c|}
\hline Depth (m) & $\begin{array}{l}\text { Transit time } \\
(\mathrm{s} / \mathrm{ft})\end{array}$ & Shale (\%) & Porosity, (\%) & $\begin{array}{l}\text { Density, } \\
\text { (g/cm3) }\end{array}$ & $\begin{array}{l}\text { Compressional velocity, } \\
\mathrm{V}_{\mathrm{p}}(\mathrm{m} / \mathrm{s})\end{array}$ \\
\hline 1431 & 136 & 85 & 37 & 2.15 & 2241.06 \\
\hline 1463 & 125 & 85 & 35 & 2.15 & 2438.28 \\
\hline 1544 & 118 & 86 & 33 & 2.18 & 2582.92 \\
\hline 1725 & 110 & 78 & 31 & 2.15 & 2770.77 \\
\hline 1876 & 100 & 74 & 28 & 2.15 & 3047.85 \\
\hline 2001 & 105 & 80 & 29 & 2.1 & 2902.71 \\
\hline 2150 & 103 & 50 & 29 & 2.25 & 2959.08 \\
\hline 2237 & 95 & 86 & 26 & 2.18 & 3208.26 \\
\hline 2323 & 95 & 80 & 26 & 2.27 & 3208.26 \\
\hline 2434 & 95 & 80 & 26 & 2.25 & 3208.26 \\
\hline 2548 & 92 & 80 & 25 & 2.2 & 3312.88 \\
\hline 2704 & 90 & 80 & 24 & 2.17 & 3386.50 \\
\hline 2835 & 85 & 88 & 22 & 2.25 & 3585.71 \\
\hline 2996 & 90 & 88 & 24 & 2.2 & 3386.50 \\
\hline 3048 & 87 & 80 & 23 & 2.3 & 3503.28 \\
\hline 3171 & 82 & 72 & 20 & 2.3 & 3716.89 \\
\hline 3200 & 85 & 72 & 22 & 2.15 & 3585.71 \\
\hline 3299 & 78 & 72 & 18 & 2.2 & 3907.50 \\
\hline 3340 & 78 & 62 & 18 & 2.3 & 3907.50 \\
\hline 3353 & 80 & 62 & 19 & 2.3 & 3809.81 \\
\hline 3409 & 80 & 62 & 19 & 2.25 & 3809.81 \\
\hline 3444 & 82 & 55 & 20 & 2.25 & 3716.89 \\
\hline 3487 & 77 & 55 & 17 & 2.4 & 3958.24 \\
\hline 3516 & 80 & 55 & 19 & 2.3 & 3809.81 \\
\hline 3530 & 80 & 60 & 19 & 2.25 & 3809.81 \\
\hline 3575 & 80 & 40 & 19 & 2.25 & 3809.81 \\
\hline 3607 & 79 & 36 & 19 & 2.25 & 3858.04 \\
\hline 3627 & 80 & 34 & 19 & 2.35 & 3809.81 \\
\hline 3639 & 71 & 31 & 14 & 2.3 & 4292.75 \\
\hline 3680 & 75 & 30 & 16 & 2.35 & 4063.80 \\
\hline 3707 & 80 & 30 & 19 & 2.25 & 3809.81 \\
\hline 3726 & 75 & 28 & 16 & 2.35 & 4063.80 \\
\hline 3780 & 75 & 28 & 16 & 2.3 & 4063.80 \\
\hline 3803 & 108 & 10 & 30 & 2.35 & 2822.08 \\
\hline 3815 & 108 & 10 & 30 & 2.35 & 2822.08 \\
\hline 3829 & 85 & 18 & 22 & 2.3 & 3585.71 \\
\hline 3840 & 85 & 18 & 22 & 2.3 & 3585.71 \\
\hline 3877 & 95 & 22 & 26 & 2.35 & 3208.26 \\
\hline 3895 & 95 & 22 & 26 & 2.35 & 3208.26 \\
\hline 3914 & 95 & 32 & 26 & 2.35 & 3208.26 \\
\hline 3932 & 95 & 32 & 26 & 2.35 & 3208.26 \\
\hline 3949 & 95 & 32 & 26 & 2.35 & 3208.26 \\
\hline 3972 & 95 & 22 & 26 & 2.3 & 3208.26 \\
\hline 4008 & 108 & 22 & 30 & 2.3 & 2822.08 \\
\hline 4023 & 100 & 24 & 28 & 2.25 & 3047.85 \\
\hline 4037 & 95 & 24 & 26 & 2.25 & 3208.26 \\
\hline
\end{tabular}


Am. J. Sci. Ind. Res., 2010, 1(2): 279-292

Table 1b: Petrophysical Parameters for Well E, Sandstone Bed

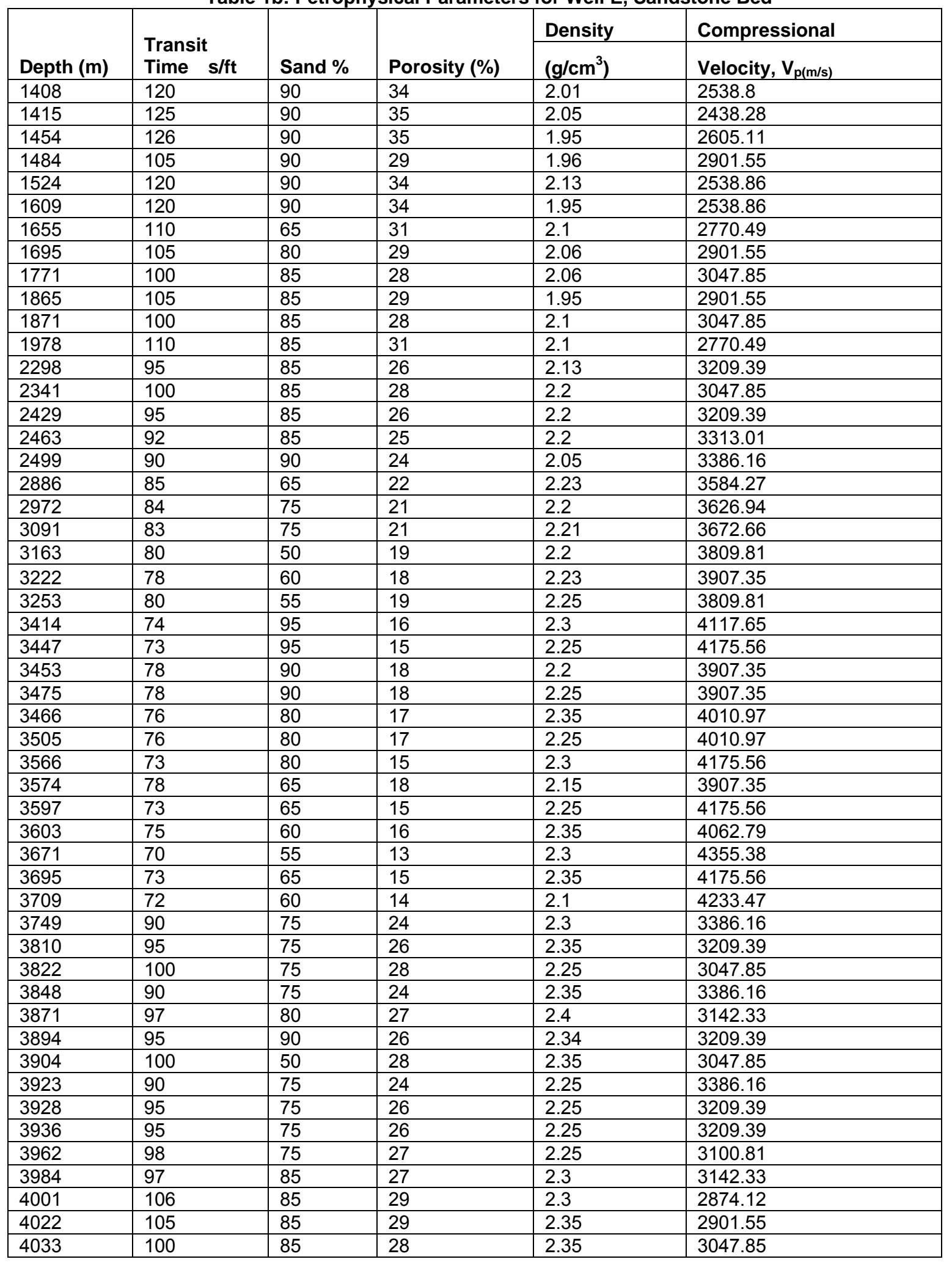


Am. J. Sci. Ind. Res., 2010, 1(2): 279-292

Table 2a: Petrophysical Parameters for Well F. Shale Bed

\begin{tabular}{|c|c|c|c|c|c|}
\hline $\begin{array}{l}\text { Depth } \\
\text { (m) }\end{array}$ & $\begin{array}{l}\text { Transit } \\
\text { time } \\
(\mathrm{s})\end{array}$ & $\begin{array}{l}\text { Shale } \\
(\%)\end{array}$ & $\begin{array}{l}\text { Porosity, } \\
\text { (\%) }\end{array}$ & $\begin{array}{l}\text { Density, } \\
\left(\mathrm{gcm}^{-3}\right)\end{array}$ & $\begin{array}{l}\text { Compressional } \\
\text { Velocity, } V_{p}\left(m^{-1}\right)\end{array}$ \\
\hline 1399 & 118 & 94 & 33 & 2.15 & 2583.05 \\
\hline 1463 & 120 & 65 & 34 & 2.18 & 2540.00 \\
\hline 1494 & 130 & 60 & 36 & 1.15 & 2344.61 \\
\hline 1551 & 124 & 76 & 35 & 2.15 & 2458.06 \\
\hline 1562 & 117 & 76 & 33 & 2.15 & 2605.12 \\
\hline 1615 & 115 & 85 & 32 & 2.27 & 2650.43 \\
\hline 1646 & 110 & 74 & 31 & 2.25 & 2770.90 \\
\hline 1728 & 110 & 70 & 31 & 2.2 & 2770.90 \\
\hline 1829 & 105 & 70 & 29 & 2.17 & 2902.85 \\
\hline 1902 & 105 & 65 & 29 & 2.25 & 2902.85 \\
\hline 2032 & 105 & 70 & 29 & 2.2 & 2902.85 \\
\hline 2109 & 105 & 58 & 29 & 2.3 & 2902.85 \\
\hline 2295 & 88 & 70 & 23 & 2.3 & 3463.63 \\
\hline 2371 & 86 & 65 & 22 & 2.15 & 3544.18 \\
\hline 2490 & 85 & 75 & 22 & 2.2 & 3585.88 \\
\hline 2551 & 83 & 60 & 21 & 2.3 & 3672.28 \\
\hline 2743 & 85 & 70 & 22 & 2.25 & 3585.88 \\
\hline 2847 & 80 & 74 & 19 & 2.25 & 3810.00 \\
\hline 2937 & 78 & 70 & 18 & 2.4 & 3907.69 \\
\hline 3040 & 73 & 64 & 15 & 2.3 & 4175.34 \\
\hline 3109 & 75 & 60 & 16 & 2.25 & 4064.00 \\
\hline 3267 & 80 & 70 & 19 & 2.35 & 3810.00 \\
\hline 3382 & 76 & 65 & 17 & 2.3 & 4010.52 \\
\hline
\end{tabular}

Table 2b: Petrophysical Parameters for Well F. Sandstone Bed

\begin{tabular}{|c|c|c|c|c|c|}
\hline Depth (m) & $\begin{array}{l}\text { Transit time } \\
\text { ( s) }\end{array}$ & $\begin{array}{l}\text { Sand } \\
(\%)\end{array}$ & $\begin{array}{l}\text { Porosity, } \\
\text { (\%) }\end{array}$ & $\begin{array}{l}\text { Density, } \\
\left(\mathrm{gcm}^{-3}\right)\end{array}$ & $\begin{array}{l}\text { Compressional } \\
\text { Velocity, Vp } \\
\left(\mathrm{ms}^{-1}\right)\end{array}$ \\
\hline 1395 & 114 & 94 & 32 & 1.15 & 2673.68 \\
\hline 1417 & 115 & 80 & 32 & 2.05 & 2650.43 \\
\hline 1489 & 118 & 65 & 33 & 2.05 & 2583.05 \\
\hline 1524 & 115 & 60 & 32 & 1.95 & 2650.43 \\
\hline 1587 & 140 & 76 & 38 & 1.95 & 2177.14 \\
\hline 1709 & 115 & 70 & 32 & 2.15 & 2650.43 \\
\hline 1842 & 120 & 50 & 34 & 2.05 & 2540.00 \\
\hline 1941 & 115 & 70 & 32 & 2.05 & 2650.43 \\
\hline 2060 & 110 & 70 & 31 & 2.35 & 2770.90 \\
\hline 2206 & 100 & 70 & 28 & 2.15 & 3048.00 \\
\hline 2312 & 95 & 58 & 26 & 2.05 & 3208.42 \\
\hline 2371 & 95 & 55 & 26 & 1.95 & 3208.42 \\
\hline 2438 & 93 & 55 & 25 & 1.95 & 3277.41 \\
\hline 2562 & 88 & 60 & 23 & 2.05 & 3463.63 \\
\hline 2638 & 85 & 60 & 22 & 2.05 & 3585.88 \\
\hline 2713 & 87 & 65 & 23 & 1.95 & 3503.44 \\
\hline 2777 & 85 & 65 & 22 & 2.05 & 3585.88 \\
\hline 2851 & 85 & 64 & 22 & 2.05 & 3585.88 \\
\hline 2929 & 77 & 70 & 17 & 1.95 & 3958.44 \\
\hline 3049 & 80 & 64 & 19 & 2.35 & 3810.00 \\
\hline 3078 & 80 & 54 & 19 & 2.05 & 3810.00 \\
\hline 3191 & 75 & 75 & 16 & 2.35 & 4064.00 \\
\hline 3274 & 80 & 70 & 19 & 2.05 & 3810.00 \\
\hline 3353 & 75 & 65 & 16 & 2.05 & 4064.00 \\
\hline
\end{tabular}


Am. J. Sci. Ind. Res., 2010, 1(2): 279-292

Table 3: Seismic Checkshots Data For Well E

\begin{tabular}{|c|c|c|}
\hline $\begin{array}{l}\text { Depth } \\
(\mathrm{m})\end{array}$ & $\begin{array}{l}\text { One way } \\
\text { travel } \\
\text { time } \\
(\mathrm{m} / \mathrm{s})\end{array}$ & $\begin{array}{l}\text { Average } \\
\text { velocity } \\
(\mathrm{m} / \mathrm{s})\end{array}$ \\
\hline 119.7 & 75 & 1596 \\
\hline 145.7 & 90 & 1619 \\
\hline 171.2 & 105 & 1631 \\
\hline 198.3 & 120 & 1653 \\
\hline 225.1 & 135 & 1667 \\
\hline 251.7 & 150 & 1678 \\
\hline 279.7 & 165 & 1695 \\
\hline 307.9 & 180 & 1711 \\
\hline 335.7 & 195 & 1722 \\
\hline 364.5 & 210 & 1736 \\
\hline 393.4 & 225 & 1748 \\
\hline 422.8 & 240 & 1762 \\
\hline 451.6 & 255 & 1771 \\
\hline 480.8 & 270 & 1781 \\
\hline 511.1 & 285 & 1793 \\
\hline 541 & 300 & 1803 \\
\hline 570.5 & 315 & 1811 \\
\hline 600.4 & 330 & 1819 \\
\hline 630.6 & 345 & 1830 \\
\hline 660.7 & 360 & 1835 \\
\hline 691 & 375 & 1843 \\
\hline 721.1 & 390 & 1849 \\
\hline 751.8 & 405 & 1856 \\
\hline 783.2 & 420 & 1865 \\
\hline 813.2 & 435 & 1869 \\
\hline 843.6 & 450 & 1875 \\
\hline 874.7 & 465 & 1881 \\
\hline 907.4 & 480 & 1890 \\
\hline 939.4 & 495 & 1898 \\
\hline 971.3 & 510 & 1905 \\
\hline 1034.8 & 540 & 1916 \\
\hline 1065.9 & 555 & 1921 \\
\hline 1099 & 570 & 1928 \\
\hline 1131.7 & 585 & 1935 \\
\hline 1165 & 600 & 1942 \\
\hline 1198.2 & 615 & 1948 \\
\hline 1234.7 & 630 & 1959 \\
\hline 1310.6 & 645 & 1973 \\
\hline 1310.6 & 660 & 1986 \\
\hline 1347.2 & 675 & 1996 \\
\hline 1383.3 & 690 & 2005 \\
\hline 1422.6 & 705 & 2018 \\
\hline 1457.1 & 720 & 2024 \\
\hline 1490.4 & 735 & 2028 \\
\hline 1523.4 & 750 & 2031 \\
\hline 1558.4 & 765 & 2037 \\
\hline 1591.5 & 780 & 2040 \\
\hline 1625.6 & 795 & 2045 \\
\hline
\end{tabular}

Table 4: Seismic Checkshots Data For Well F

\begin{tabular}{|c|c|c|}
\hline $\begin{array}{l}\text { Depth } \\
\text { (m) }\end{array}$ & $\begin{array}{l}\text { One way } \\
\text { travel } \\
\text { time, } \\
(\mathrm{m} / \mathrm{s})\end{array}$ & $\begin{array}{l}\text { Average } \\
\text { velocity } \\
(\mathrm{m} / \mathrm{s})\end{array}$ \\
\hline 475.82 & 282 & 1687 \\
\hline 501.89 & 295 & 1707 \\
\hline 530.39 & 310 & 1717 \\
\hline 562.9 & 325 & 1732 \\
\hline 593.4 & 340 & 1745 \\
\hline 623.9 & 355 & 1758 \\
\hline 654.4 & 370 & 1769 \\
\hline 684.91 & 385 & 1779 \\
\hline 715.41 & 400 & 1789 \\
\hline 747.23 & 415 & 1801 \\
\hline 779.63 & 430 & 1813 \\
\hline 812.03 & 445 & 1825 \\
\hline 844.43 & 460 & 1836 \\
\hline 876.83 & 475 & 1846 \\
\hline 909.24 & 490 & 1856 \\
\hline 941.64 & 505 & 1865 \\
\hline 974.04 & 520 & 1873 \\
\hline 1007.42 & 535 & 1893 \\
\hline 1040.59 & 550 & 1892 \\
\hline 1068.98 & 565 & 1892 \\
\hline 1107.19 & 580 & 1909 \\
\hline 1133.49 & 595 & 1905 \\
\hline 1169.03 & 610 & 1916 \\
\hline 1197.78 & 625 & 1917 \\
\hline 1231.83 & 640 & 1925 \\
\hline 1265.82 & 655 & 1933 \\
\hline 1306.64 & 670 & 1950 \\
\hline 1341.59 & 685 & 1959 \\
\hline 1378.07 & 700 & 1969 \\
\hline 1410.73 & 715 & 1973 \\
\hline 1451.21 & 730 & 1988 \\
\hline 1499.06 & 745 & 1997 \\
\hline 1522.49 & 760 & 2003 \\
\hline 1557.65 & 775 & 2010 \\
\hline 1593.79 & 790 & 2018 \\
\hline 1628.37 & 805 & 2023 \\
\hline 1664.02 & 820 & 2029 \\
\hline 1701.98 & 835 & 2038 \\
\hline 1740.13 & 850 & 2047 \\
\hline 1764.49 & 865 & 2040 \\
\hline 1791.7 & 880 & 2036 \\
\hline 1844.46 & 895 & 2061 \\
\hline 1888.03 & 910 & 2075 \\
\hline 1923.97 & 925 & 2080 \\
\hline 1962.59 & 940 & 2088 \\
\hline 2009.42 & 955 & 2104 \\
\hline 2043.82 & 970 & 2107 \\
\hline 2046.27 & 976 & 2097 \\
\hline
\end{tabular}


Am. J. Sci. Ind. Res., 2010, 1(2): 279-292

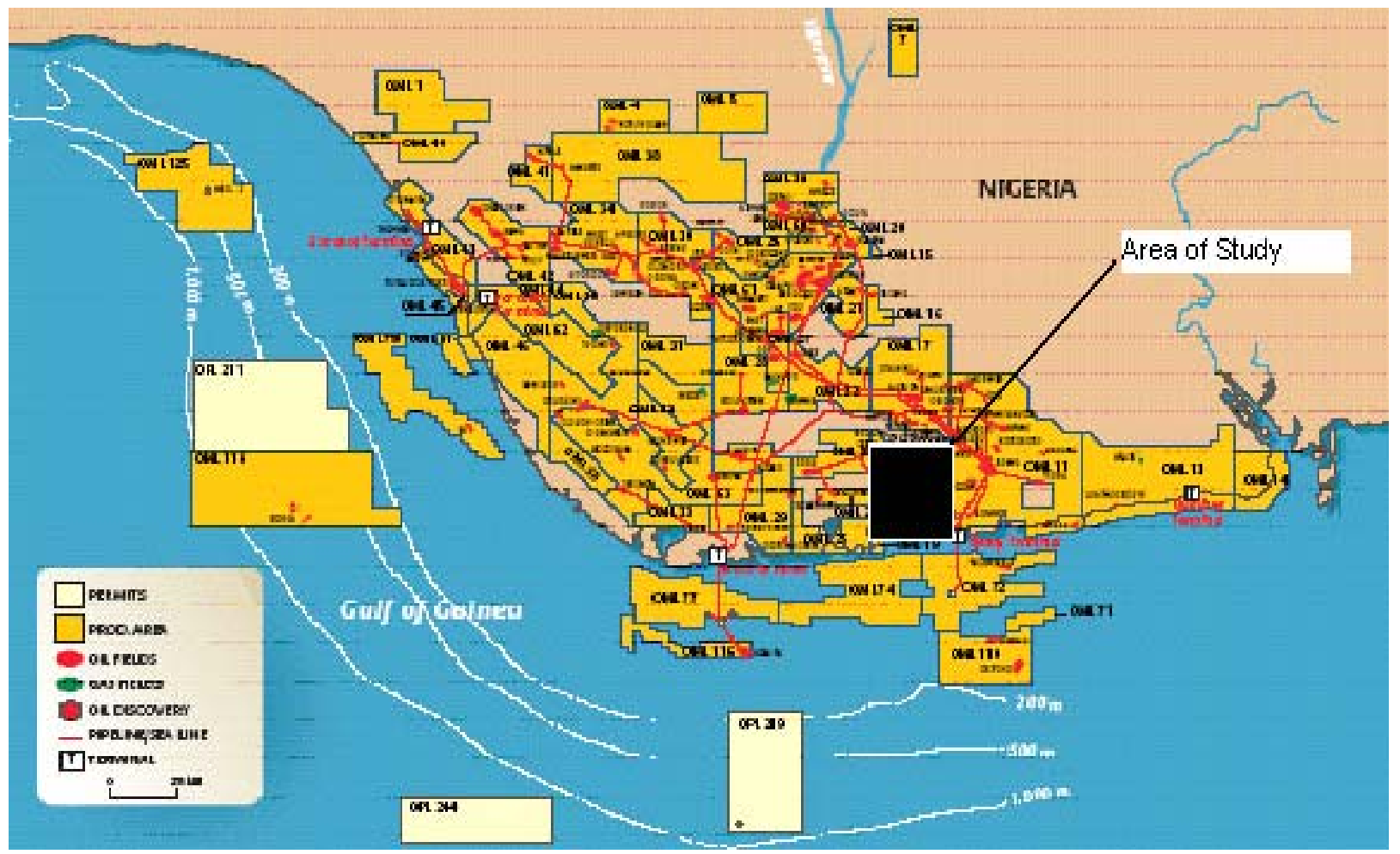

Fig. 1: Map of the Niger Delta basin showing the study area

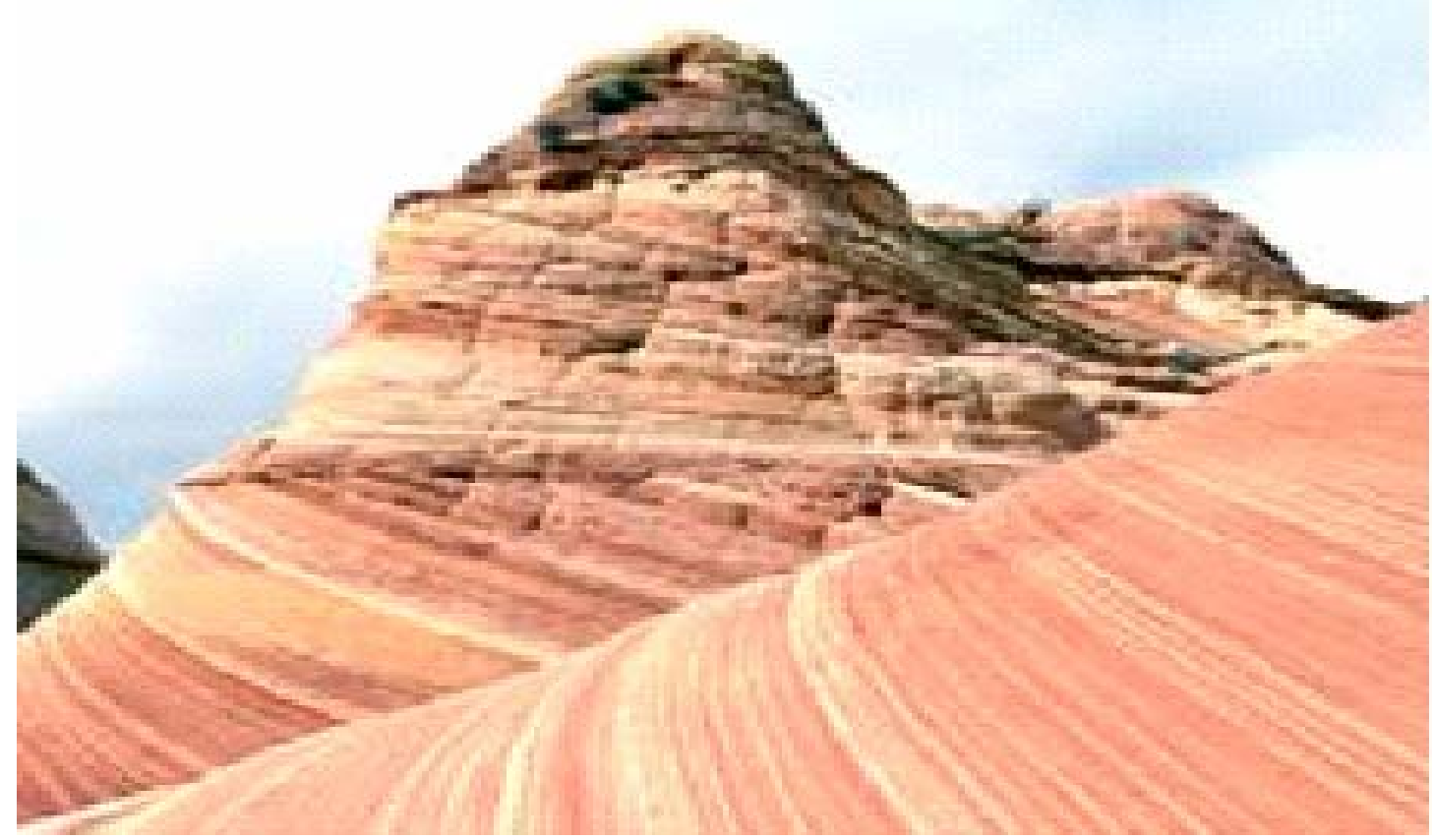

Fig. 2: Minor Stratifications of a Sedimentary Rock Body 
Am. J. Sci. Ind. Res., 2010, 1(2): 279-292

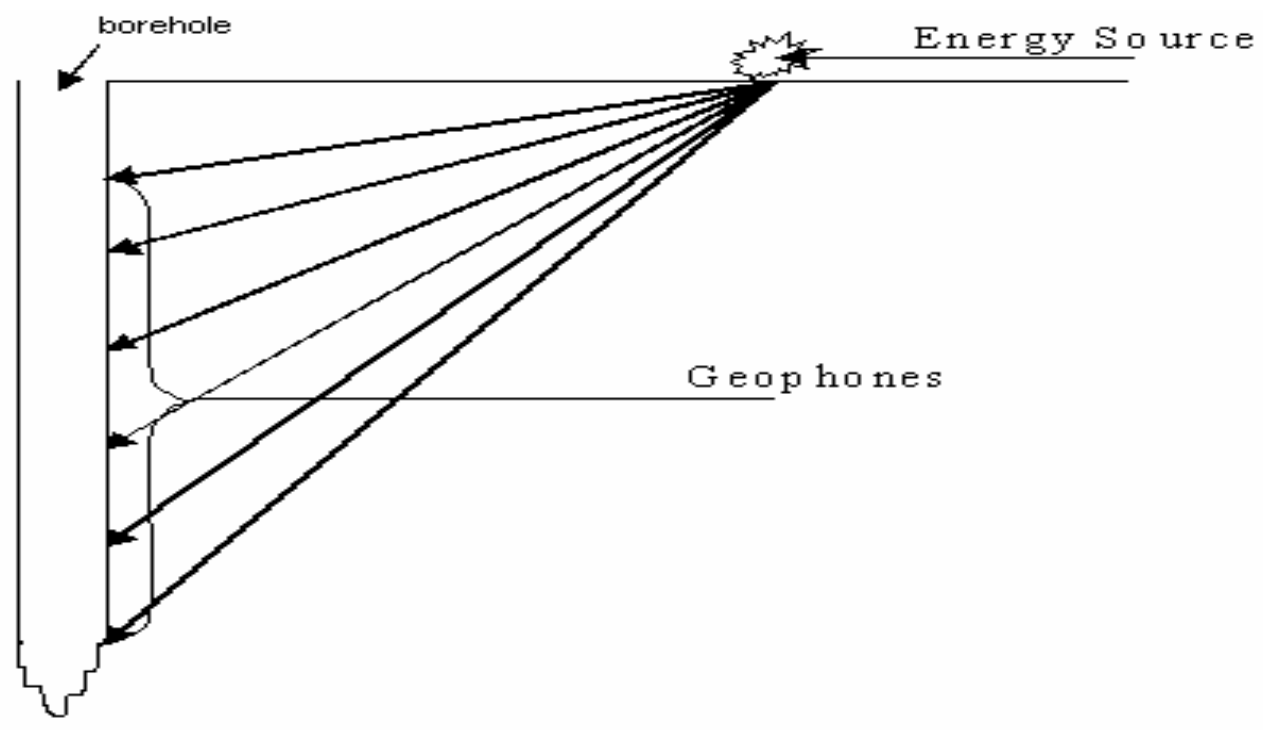

Fig. 3: Diagrammatic presentation of Checkshot Survey

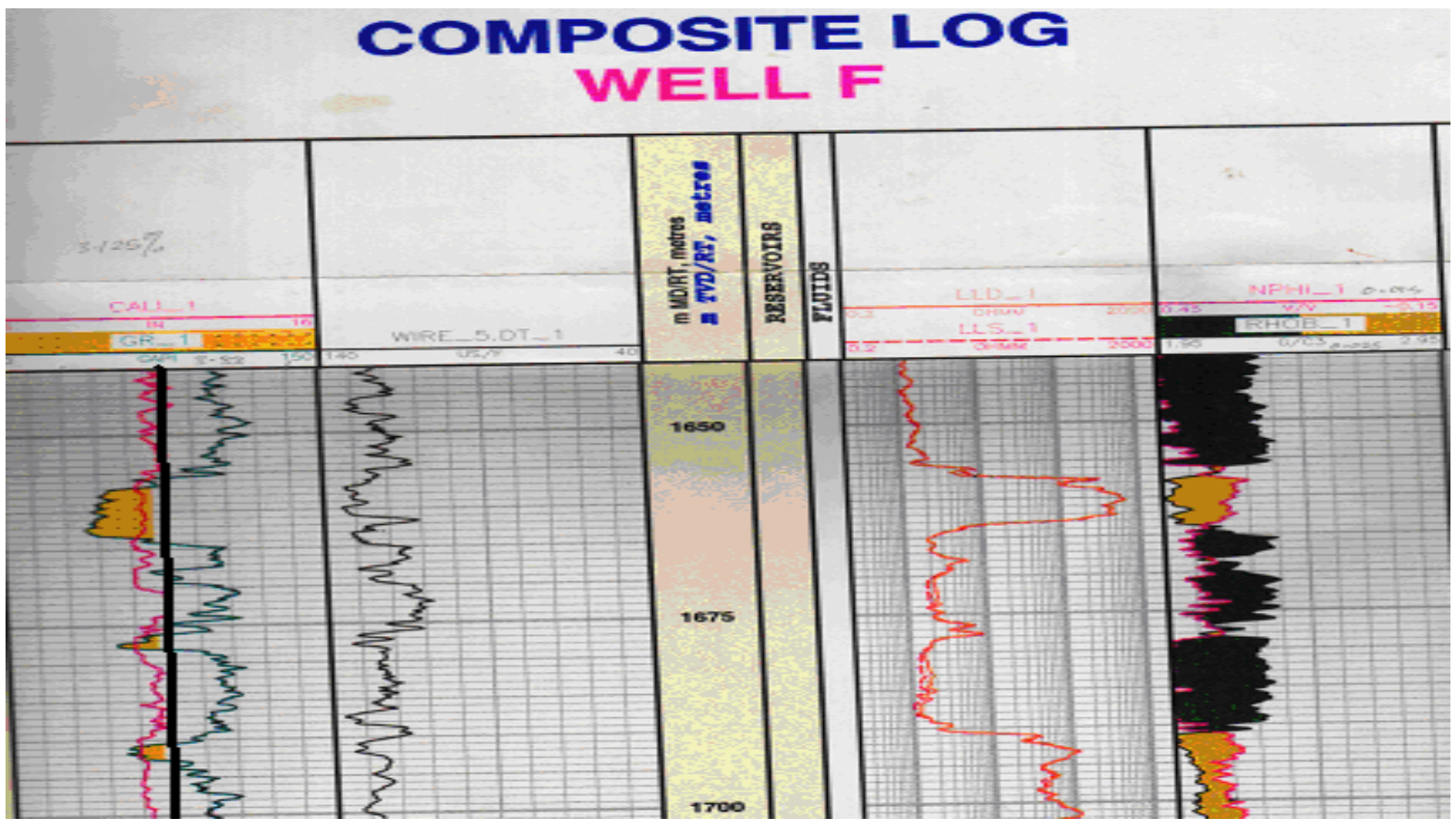

Fig. 4: Typical Composite Log showing Gamma ray log, Sonic log and Bulk Density log 


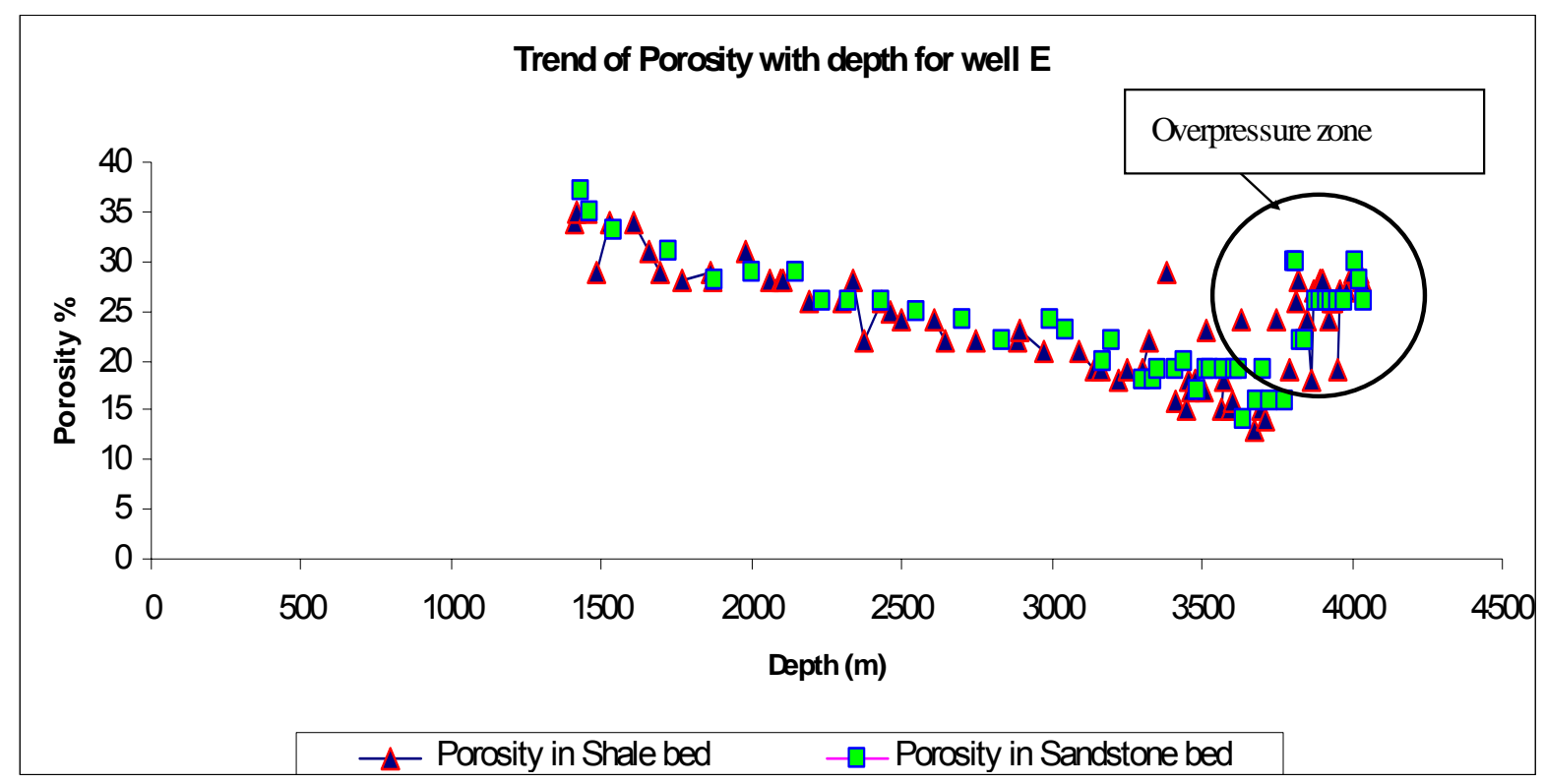

Fig. 5: Showing the Trend of Porosity with Depth for Well E

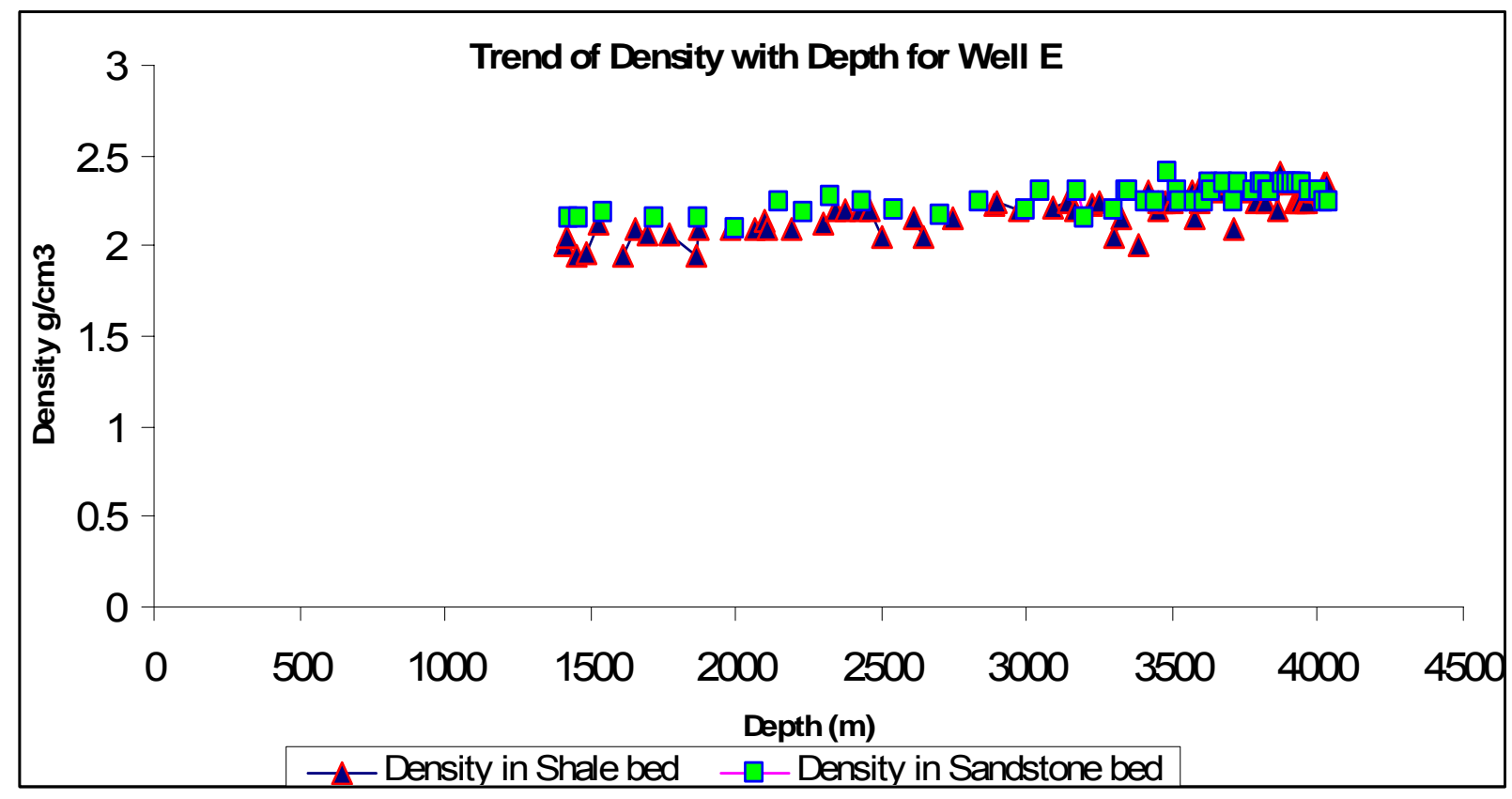

Fig. 6: Showing the Trend of Density with Depth for Well E 


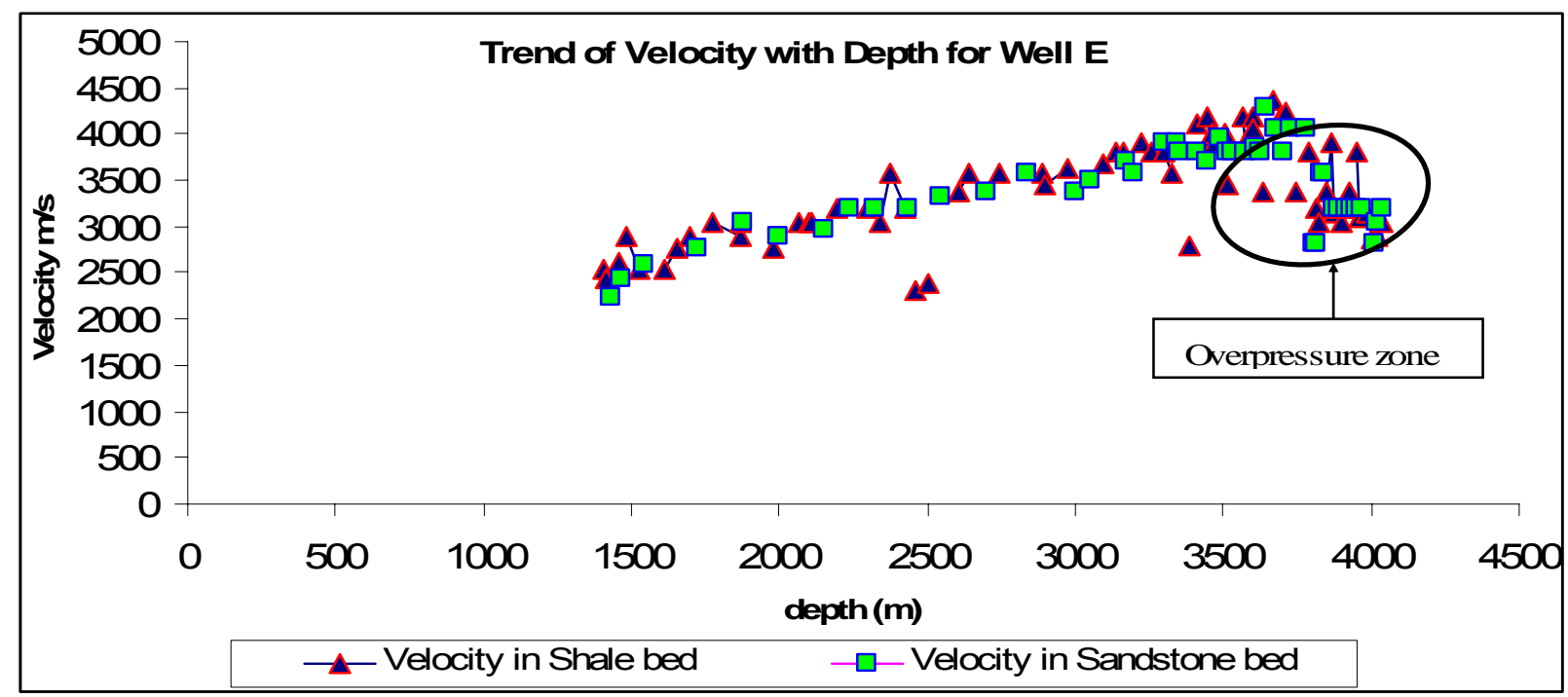

Fig. 7: Showing the Trend of Velocity with Depth for Well E

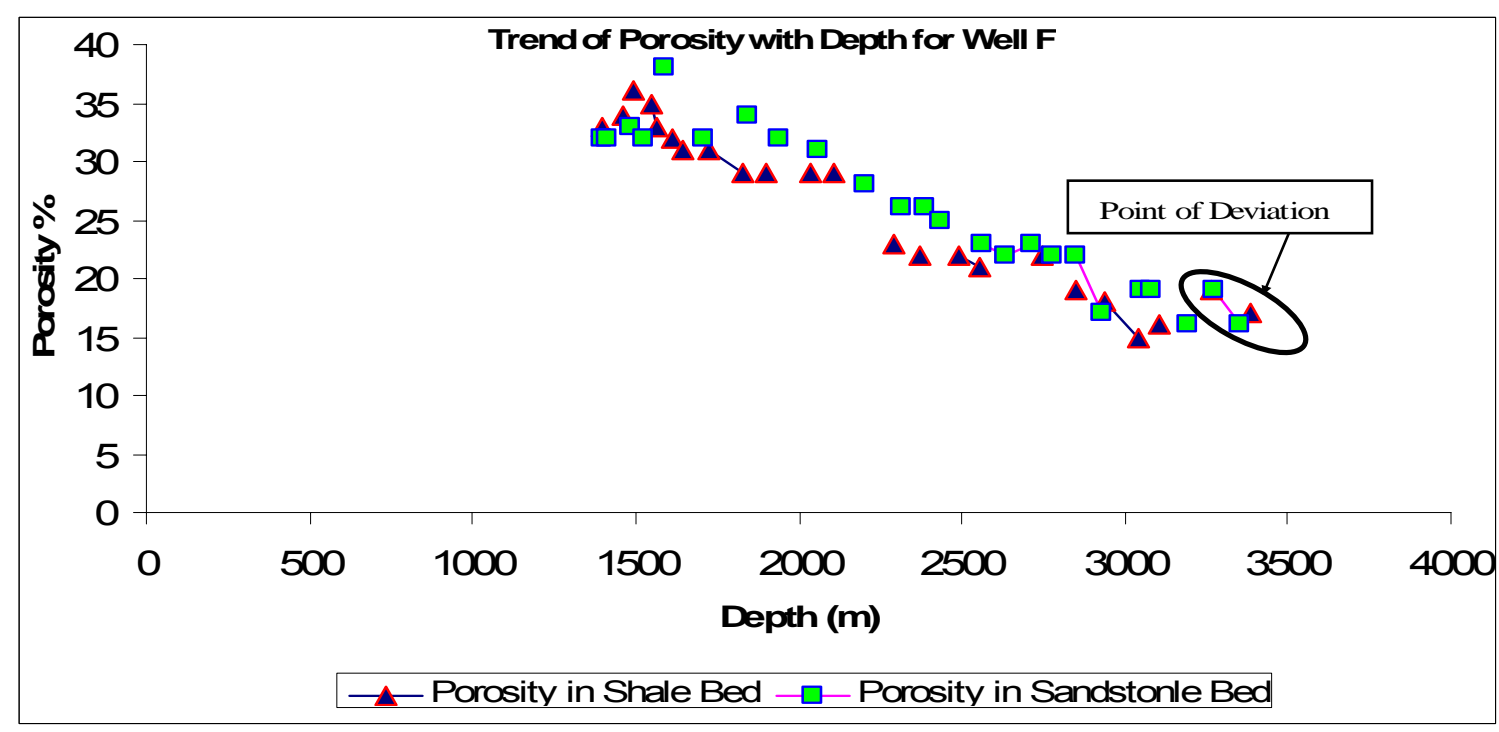

Fig. 8: Showing the Trend of Porosity with Depth for Well F 


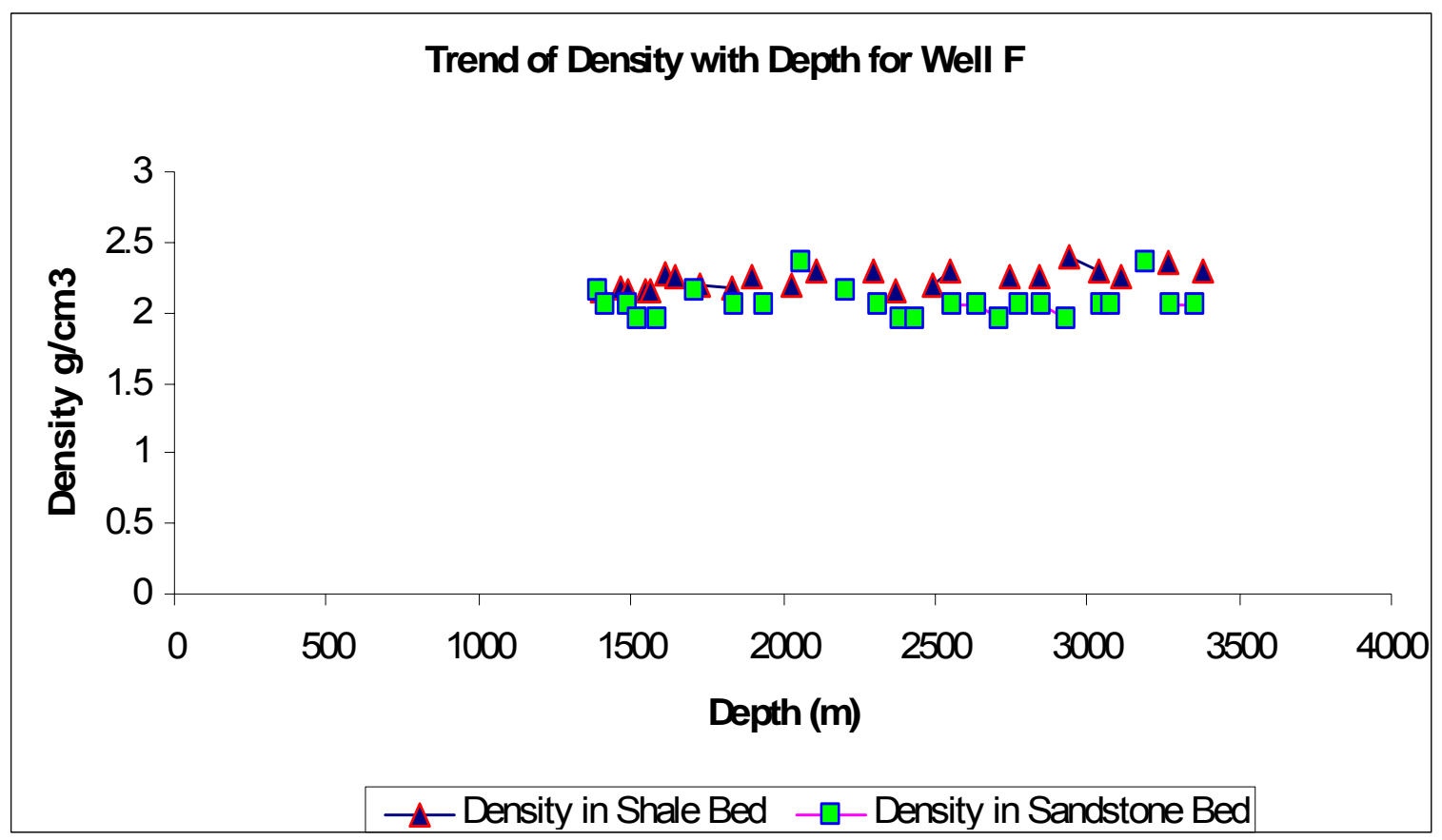

Fig. 9: Showing the Trend of Density with Depth for Well F

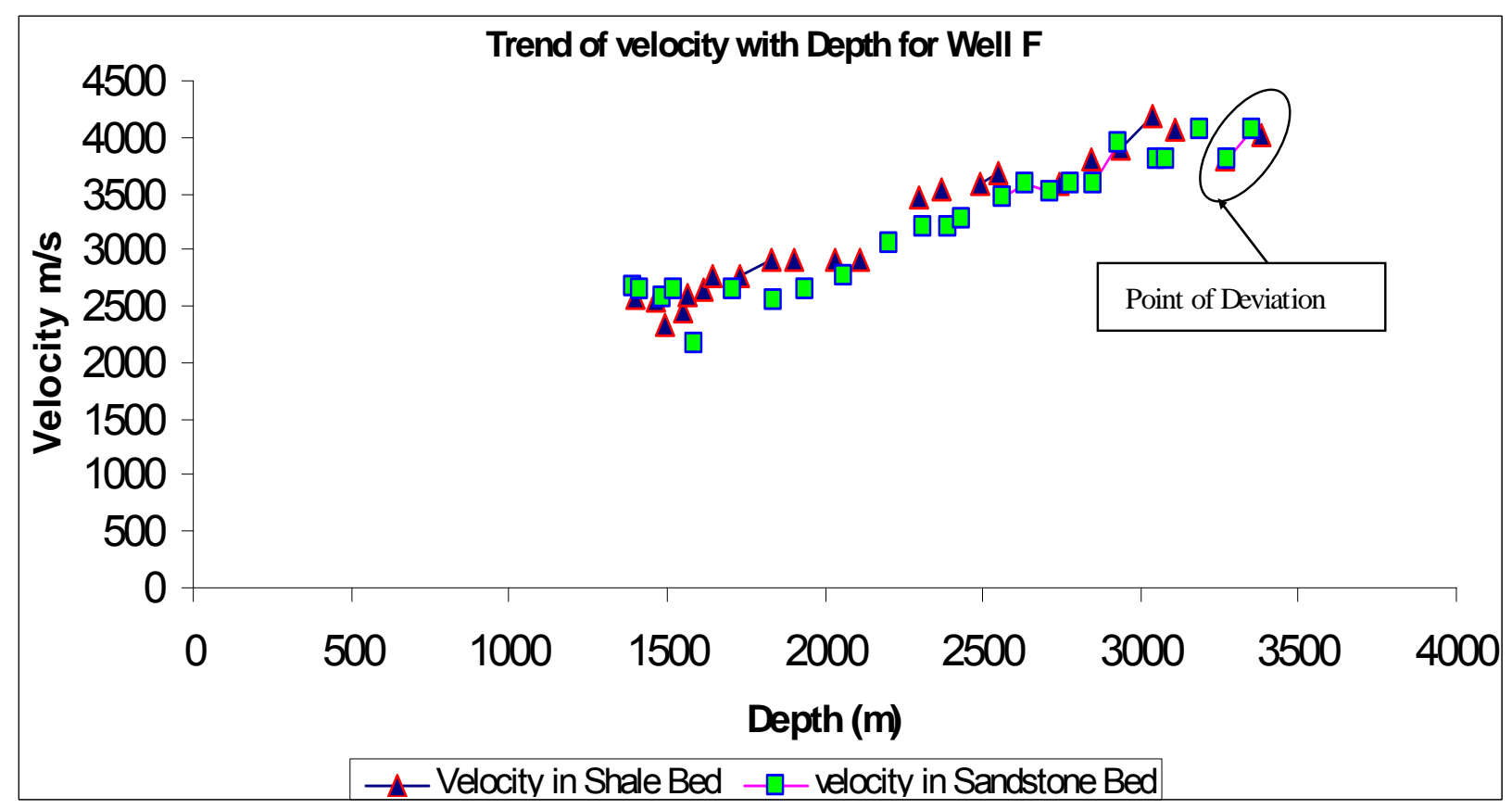

Fig. 10: Showing the Trend of Velocity with Depth for Well F 
Am. J. Sci. Ind. Res., 2010, 1(2): 279-292

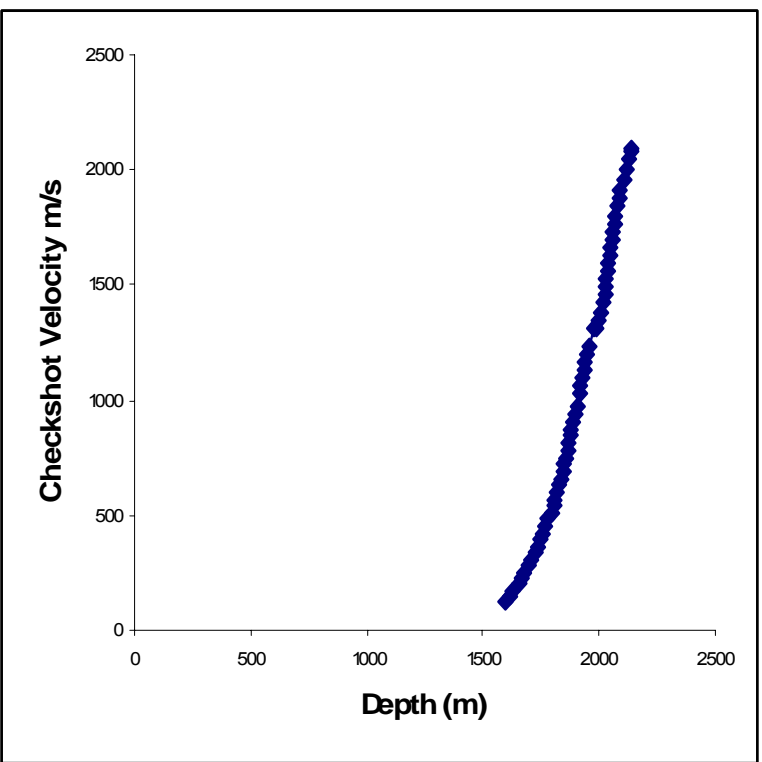

Fig. 11: Trend of Checkshot Velocity with Depth for Well

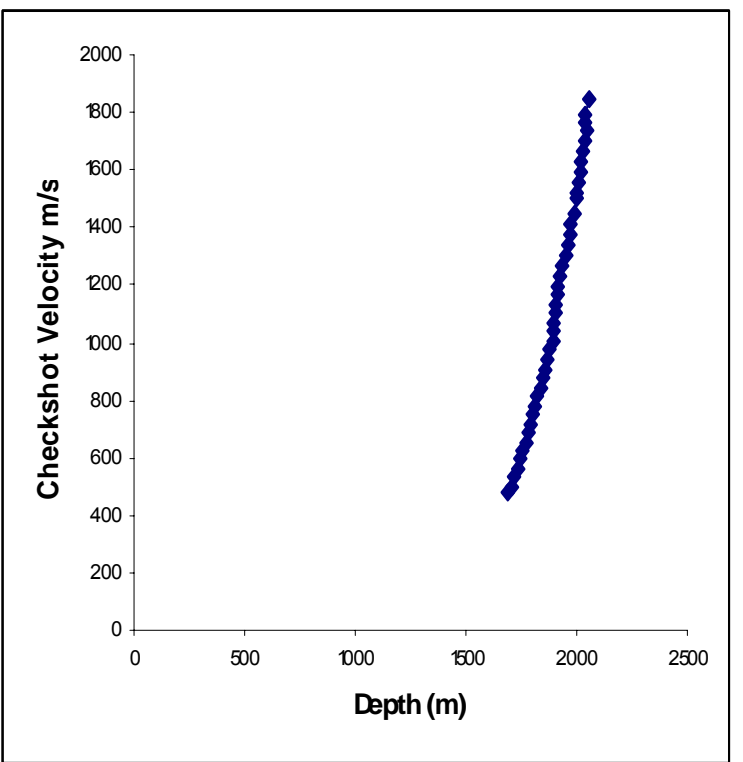

\section{for Well E}

Success Computers for their assistance in data analysis.

\section{REFERENCES}

Assimaki, D; Steidl, J; and Liu, P.G; 2006. Attenuation and Velocity Structure for Site Response Analysis via Downhole seismogram Inversion, Pure Appl. Geophysics, 163, $81-118$.

Bosch, M; Zamora, M; and Utama, W; 2002. Lithology Discrimination from Physical Rock Properties, Geophysics, 67, $573-581$.

Brigand, F; Chapman, D.S; andDouaran, S.L; 1990. Estimating Thermal Conductivity in Sedimentary Basin using Lithologic Data and Geophysical Well Logs. AAPG. Bull., 74(9), $1459-1477$

Delahaye, E.J; Townend, J; Reyners, M.E; and Rogers, G; 2009. Microseismicity but no Tremor Accompanying Slow Slip in the Hikurangi Subduction Zone, New Zealand. Earth and Planetary Science Letters, 277, 21 $-28$.

Fraser, H.J; 1935. Experimental Study of Porosity and Permeability of Clastic Sediments. Journal of Geology, 43, $910-1010$.

Judson, D.R; Lin, J; Schultz, P.S; and Sherwood, J.W.C; 1980. Depth Migration after Stack. Geophysics, 45, $376-393$

Payero, J.S; Kostoglodov, V; Shapiro, N; Mikumo, T; Iglesias, A; Prez-Campos, X; and Clayton, R; 2008. Nonvolcanic Tremor Observed in the Mexican Subduction Zone. Geophysical Research Letters, 35. doi: 10.1029/2007GL03877. 
Am. J. Sci. Ind. Res., 2010, 1(2): 279-292

Plona, T.J; and Johnson, D.L. 1984. Acoustic Properties of Porous Systems: Phenomenological description: In Physics and chemistry of Porous Media. Edited by D.L. Johnson and P.N. Sen. American Institute of Physics, New York.

Plummer, C.C; and McGeary, D; 1993. "Physical Geology", $6^{\text {th }}$ Ed. Wm.C. Brown Publishers, England.

Polymenakos, L; Papamarinopoulos, S; Miltiadou, A; and Charkidakis, N. 2005. Investigation of the Foundation of a Byzantine church by Three-Dimension Seiemic Tomography. Journal of Applied Geophysics, 57, 81 93.

Prasad, M; 2002. Acoustic Measurements in Unconsolidated Sand at Low Effective Pressure and Overpressure Detection. Geophysics, 67(2), 405 412.
Schlumberger, $1987 . \quad$ Log Interpretation: Principles/Applications. Schlumberger Education Services, USA.

Shelly, D.R; Beroza, G.C; and Ide, S; 2007. Non-Volcanic Tremor and Low-frequency Earthquake Swarms. Nature, 446(7133), 305 - 307. doi: 10.1038/nature05666.

Sheriff, R.E; 1991. "Encyclopaedic Dictionary of Exploration Geophysics", $3^{\text {rd }}$ Ed. Society of Exploration Geophysicists, USA.

Short, K.C; and Stauble, A; 1967. Outline of Geology of the Niger Delta. AAPG. Bull. 51, 761 - 779.

Udias, A; 1999. "Principles of Seismology", Cambridge University Press, Cambridge, UK.

Uko, E.D; Amakiri, A.R.C; and Alagoa, K.D; 2002. Effects of Lithology on Geothermal Gradient in the South-east Niger Delta. Global Journal of Pure and Applied Science, 9(3), $325-337$. 